\title{
Prácticas etnográficas reinventadas El quehacer textil y audiovisual como narrativas de la memoria*
}

\author{
Ethnographic practices reinvented \\ Textile art and audiovisual documentation \\ as memory narratives
}

\author{
MARIANA XOCHIQUÉTZAL RIVERA GARCÍA**
}

\begin{abstract}
Two different ethnographic methodologies are interwoven in this text: the textile art and the audiovisual documentation, both of them as aesthetic experiences that call forth social organization and collective action within contexts of violence. The exercising of memory and the bodily work that these ethnographic proposals imply, have allowed me to conduct research on such dreadful subjects as forced disappearance from a perspective of affection, sensitivity and full commitment. It was through the art of weaving that I got to know the People-Searching Collective from the state of Michoacán, Mexico. Meeting this collective encouraged me to create an audiovisual document from the Fifth Searching-for-the-Disappeared Caravan, which took place in the above-mentioned state, in May 2019. This experience shows the importance of interdisciplinary methodologies to document memory. The valuation of textile and audiovisual testimonies contributes to the recognition of the victims as creators and agents of social chance.
\end{abstract}

Key words: violence, methodologies, visual anthropology, inter-discipline, testimonial textiles

\begin{abstract}
Resumen
Dos metodologías etnográficas se entrelazan en este texto: la práctica textil y el quehacer audiovisual, ambas como experiencias estéticas que invitan a la organización social y acción colectiva en contextos de violencia. El ejercicio de la memoria y el quehacer corpóreo que implican ambas apuestas etnográficas permitieron investigar desde una dimensión afectiva, sensible $y$ comprometida temas tan terribles como la desaparición forzada. A través del tejido la autora conoció a uno de los colectivos de búsqueda en el estado de Michoacán, México, lo que la animó a realizar la documentación audiovisual durante el acompañamiento a la V Caravana de Búsqueda de Personas Desaparecidas realizada en dicho estado en mayo de 2019. Esta experiencia muestra la importancia de las metodologías interdisciplinarias para documentar la memoria. La puesta en valor de los testimonios textiles $y$ audiovisuales contribuye a reconocer a las víctimas como creadoras y agentes de cambio social.
\end{abstract}

Palabras clave: violencia, metodologías, antropología visual, interdisciplina, textiles testimoniales

\footnotetext{
* Artículo recibido el 05/02/21 y aceptado el 19/05/21.

** Instituto Nacional de Antropología e Historia-Dirección de Etnología y Antropología Social. Av. San Jerónimo 880, col. San Jerónimo Lídice, 10100 Magdalena Contreras, Ciudad de México <mariana_rivera@inah.gob.mx>. oRciD: https:// orcid.org/0000-0002-2456-1414
} 


\section{Introducción}

$\mathrm{E}$ 1 título de este artículo es una invitación a reflexionar alrededor de dos prácticas que de forma aislada parecerían tener poca relación con la etnografía o la teoría antropológica: el quehacer textil y el audiovisual, sin embargo, invito a pensar estas prácticas de manera reinventada, en el sentido de poder ver en ellas potenciales narrativos, espacios de escucha, reflexión, representación y, sobre todo, construcción de relaciones sociales que se tejen alrededor de ellas cuando las ponemos al servicio de la etnografía, ya que permiten construir conocimiento antropológico desde un lugar donde se privilegia lo sensible, pues, en esencia, son actividades que permiten acompañar procesos sociales atravesados por el dolor.

En este texto retomo mi experiencia etnográfica en relación con estas dos prácticas mencionadas y articuladas metodológicamente. Por un lado, la práctica textil entendida como el quehacer que involucra el uso creativo de hilos, telas y agujas y, por el otro, el trabajo audiovisual en cuanto registro, proceso de conocimiento y evocación de la trama etnográfica que busca la emocionalidad de lo que está siendo retra- tado. Ambas labores nos hacen ejercitar una mirada al investigar, desarrollar una sensibilidad para comprender que estos dispositivos narrativos son soportes testimoniales que deben entenderse y estudiarse en su dimensión poética, simbólica y afectiva, para elaborar a partir de ellos lenguajes etnográficos que conmuevan y promuevan una posible transformación social.

Desde hace varios años se ha fortalecido una línea de investigación antropológica que incorpora las prácticas textiles como narrativas testimoniales y metodologías puestas en marcha en contextos donde las personas viven distintos tipos de violencias y donde es necesario que se les considere como algo más que sólo víctimas (González-Arango, 2019; Bello y Aranguren, 2020; Quiceno Toro y Villamizar Gelves, 2020). La expresión colectiva mediante la creación, en este caso textil, da lugar a la enunciación de testimonios de actos atroces que han dejado huella sobre los cuerpos de las personas. Cuando las palabras no alcanzan para nombrar el dolor se ha encontrado en el quehacer sensible de los hilos un modo de contar, de sanar y compartir con otros lo vivido, lo cual crea unión, complicidad y comunidad.

Foto 1

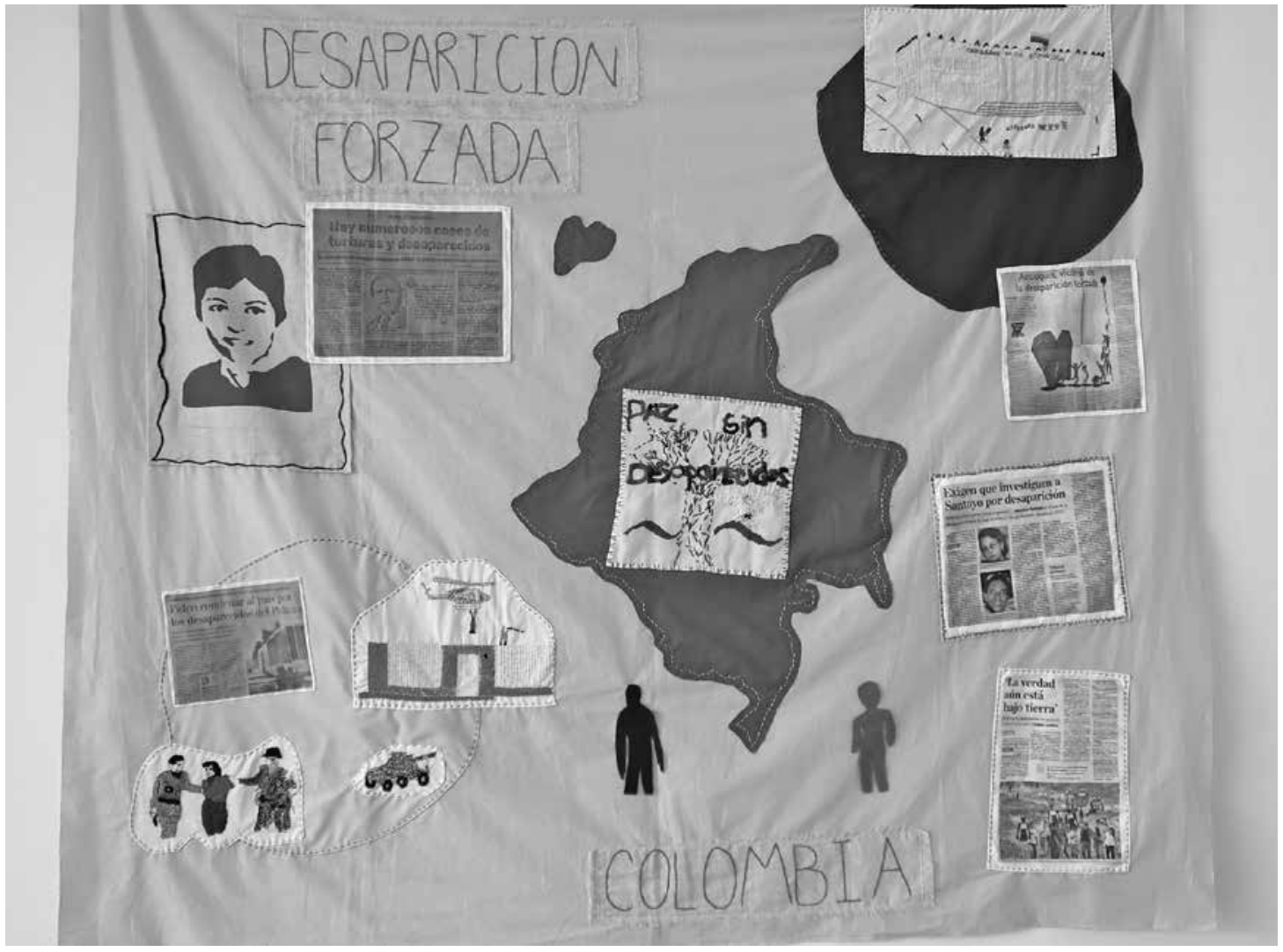

Desaparición forzada en Colombia. Retratos de una búsqueda. Tapiz creado por la Asociación de Familiares de Detenidos Desaparecidos (transferencia sobre tela, costura y bordado) (foto: Mariana Rivera). 
El tejido ha sido un ejercicio reparador, que comunica a través de la especificidad de su soporte y materialidad cierto tipo de información que ha pasado por el cuerpo y reflexión de quien tejió o bordó la historia que quedó plasmada sobre la tela a modo de testimonio. "Las realidades que estudiamos afectan nuestras prácticas de investigación" afirma Tania Pérez-Bustos (2019: 2), investigadora colombiana que ha puesto en marcha los haceres textiles como experiencias etnográficas. Ella explora en la costura como escritura y señala que estas etnografías sobre lo textil son afectadas por la propia especificidad de la práctica, lo que significa poner las manos sobre esta labor para entender el verdadero lenguaje y significado de lo que estudiamos. En consecuencia, uno de los aspectos esenciales de esta práctica, y que comparto con la autora, ya que ambas somos además tejedoras, es que el quehacer textil es colectivo, porque se aprende en grupo, lo cual presupone una cercanía corporal entre las tejedoras que se enseñan e intercambian puntadas. Esto mismo ocurre en la etnografía, se requiere reforzar esa cercanía corporal con el otro para comprenderlo.

Además, la documentación fotográfica, cinematográfica y audiovisual son prácticas que han acompañado a la disciplina antropológica desde la invención de los artefactos que permiten retratar el espacio en el tiempoy hacerlo perdurar como una memoria. Respecto a los medios audiovisuales en cuanto herramientas de investigación se ha publicado bastante, pues estos medios se han practicado de diversas maneras, la más obvia de ellas es la producción documental, ya sea de forma narrativa, expositiva, observacional, periodística, inmersiva o experimental sobre un tema antropológico. También se ha concebido el audiovisual como un diario de campo etnográfico que conlleva cierto rigor (Grau, 2008). Otra dimensión la ocupan el análisis y la circulación que tienen las obras producidas en distintos entornos, ya sea con fines pedagógicos o de difusión, es decir, cómo es que estas obras impactan sobre cierta realidad (Ardévol, 2008). Pero poco se ha reflexionado sobre el proceso afectivo que una producción audiovisual conlleva para sus realizadores, los sujetos retratados y su entorno emocional. Este establecimiento emotivo, mediado por una complicidad y acuerdo mutuo entre quien sostiene la cámara y quien está frente a ella, es algo que aquí nos ocupa más allá del producto finalizado. Para el caso de este artículo pondré énfasis en la experiencia del acompañamiento audiovisual de la V Caravana de Búsqueda de Personas Desaparecidas en el estado de Michoacán en mayo de 2019.

La reflexión que guía este artículo plantea dos premisas principales: la primera fincada en la necesidad de diseñar estrategias metodológicas que permitan investigar de mejor forma realidades complejas en condiciones extremas. Y, la segunda, pensar los factores sociales de vulnerabilidad que exponen a poblaciones a padecer violencias, así como las implicaciones emocionales, físicas, afectivas, psicológicas y culturales que tiene la exposición a situaciones de riesgo para quienes hacemos investigación en estos contextos.

\section{Metodologías experimentales para el trabajo de campo en contextos de violencia}

La práctica antropológica mediada por una metodología textil y audiovisual ha sido recurrente en mi quehacer investigativo. Desde hace más de 15 años soy tejedora y me he podido vincular a experiencias etnográficas y colectivos textiles que utilizan este medio como una forma de narrar la violencia, de denunciar actos de injusticia y de apoyarse mutuamente a través del espacio compartido para tejer y trabajar con el dolor. De hecho, la metodología textil no es algo que yo haya inventado, sino algo que hemos venido trabajando colaborativamente entre colegas antropólogas, tejedoras $\mathrm{y}$ artistas que se han interesado en acompañar a víctimas de la violencia. A la par del trabajo textil, como antropóloga visual y documentalista, he procurado experimentar con el sonido y la imagen en movimiento en casi todas mis investigaciones. Mi aproximación es variada y va desde la ficción etnográfica hasta la rítmica sonora de la cultura textil. La cámara me ha ayudado a conocer y mirar de otra manera la realidad que estudio y en la cual me involucro con todos los sentidos. Etnografiar desde el textil y el audiovisual han sido posibilidades de acción y colaboración con las comunidades de estudio por medio de la creatividad y cocreación que ambas prácticas requieren.

La creación de metodologías pensadas y diseñadas para contextos particulares con herramientas y conocimientos de distintas disciplinas es lo que algunos antropólogos denominan metodologías experimentales. Este concepto alude a aquellas prácticas que subvierten las convenciones históricas sobre el empirismo, objetividad y veracidad, convencionalmente asociados a la etnografía. "La etnografía experimental se refiere a repensar tanto la estética como la representación cultural" (Russell, 1999: 11). Este tipo de etnografía, según Russell, debe subvertir las diferentes estructuras de racismo, sexismo e imperialismo que están implícitas en las representaciones culturales.

La combinación del dispositivo textil-audiovisual ha sido una armoniosa relación que me ha permitido 
constatar cómo estas narrativas de la memoria se complementan y refuerzan. Por un lado la creación textil que es reflexiva y, por el otro, la creación audiovisual que posibilita retratar ese proceso desde lo íntimo, evocando la experiencia del etnógrafo y facilitando que el registro mismo no sólo sea fuente de conocimiento sino memoria viva.

En este apartado metodológico lo que me interesa es abordar la idea de la interdisciplina, de modo que las metodologías y herramientas que adoptamos de otras áreas del conocimiento, como lo es la cámara o el arte textil, nos abran la puerta para entrar de modo cuidadoso y amable al estudio de realidades desgarradoras. También quiero poner en cuestión las estrategias metodológicas que normalmente aprendemos en las aulas y que no siempre se adaptan o responden a las situaciones extremas que enfrentamos en el trabajo de campo contemporáneo.

Los métodos de investigación no sólo afectan aquello que estudian, son afectados por esto. Reconocer dicha afectación en esa doble vía implica reconocer que devenimos investigadoras e investigadores con las realidades que estudiamos: ellas nos afectan, nos interpelan, interfieren en nuestros métodos, nos construyen como sujetos que investigamos [Pérez-Bustos, 2019: 2].

La creación artística como medio creativo de expresión es retomada por la antropología para generar diversidad de relatos y formas sociales y/o comunitarias de poder hablar y analizar nuestra realidad.

Después de la denominada crisis de la representación, diversos autores que cuestionaban la autoridad etnográfica y las formas de escritura y de comunicación antropológica ya argüían sobre la necesidad de una antropología performativa, que pusiera en escena fragmentos de realidad para comunicar de maneras más sensibles y creativas información considerada científica desde una perspectiva académica: "Necesitamos formas, experimentos con formas, modos alternativos y representativos [performative modes] de investigación para conformar discusiones teóricas y de otros tipos sobre los problemas antropológicos" (Elhaik y Marcus, 2012: 89).

En Colombia, a partir del estudio antropológico del conflicto y posconflicto armado, los antropólogos e historiadores incursionaron en metodologías que de algún modo ponen en escena realidades complejas y muchas veces dolorosas. Entre estas expresiones encontramos el teatro, las muestras curatoriales, las exposiciones rodantes, los documentales, los videoclips, la creación de canciones y tejidos que nos hablan de la lucha y resistencia de los pueblos ante la violencia. Una de estas antropólogas es Pilar Riaño, quien experimenta con las categorías de memoria como metodología para una antropología del recuerdo y el olvido. Su trabajo me ha inspirado en cuanto creadora de metodologías que le han permitido hacer etnografía en espacios sumamente violentos en Colombia y establecer genuinas relaciones de colaboración con los jóvenes protagonistas de sus investigaciones.

Subvirtiendo la iniciativa etnográfica tradicional, propongo que los temas de la autoridad antropológica, la voz y la mirada necesitan resolverse al nivel de la praxis, más que al nivel textual o conceptual. Teniendo la praxis como centro, uno es capaz de alternar la etnografía, en tanto texto o género, con las pragmáticas y procesos con que se conducen la investigación y el trabajo de campo: las maneras en que el investigador se relaciona con los sujetos y las comunidades estudiadas, las contribuciones tangibles que puede aportar la investigación a los procesos sociales y a las comunidades, y el uso de métodos que alienten procesos dialógicos y reflexivos [Riaño, 2006: 43].

Las expresiones textiles y audiovisuales, en el sentido que expresa Riaño, además de responder a una búsqueda estética, son prácticas que existen sólo en el intercambio y consenso humano, es decir, éstas suceden únicamente al calor del encuentro con otros, en su reconocimiento desde la sensibilidad humana. Apelan a lo que Jimeno, Castillo y Varela (2012) han denominado comunidades emocionales.

Tim Ingold también ha dedicado parte de su obra a la reflexión en torno a la etnografía. En uno de sus artículos “'Suficiente con la etnografía!” (2017), nos invita a concebir la antropología y sus técnicas como prácticas de aprendizaje o correspondencia, donde la etnografía deja de ser el adjetivo que acompaña a casi cualquier concepto, para volver a la antropología en cuanto proceso de aprendizaje que debe privilegiarse por sobre los productos derivados de la investigación.

¿Qué pasa entonces cuando, además, el trabajo de campo implica poner la vida en riesgo?

Es inevitable la pregunta sobre nuestra materia de estudio y el papel que tenemos los antropólogos ¿Hasta dónde somos sólo científicos sociales y observadores? ¿Cuál es el límite que divide la práctica etnográfica, el compromiso social y nuestra capacidad de resistir la adversidad? Los contextos de estudio son cambiantes, y nuestro papel-antes incontestablemente científico-, es ahora definido por el interés particular de cada investigador según su criterio y congruencia ética con su quehacer. Esto determinará si el investigador decide tan sólo observar y describir, o si opta por involucrarse, investigar, denunciar y colaborar con las luchas 
decretadas por las comunidades. Tener objetivos claros en nuestra tarea de interpretación y comunicación antropológica nos abrirá la puerta a tener una mirada crítica hacia nuestra disciplina.

Con la integración de tecnologías, prácticas y áreas de conocimiento, la antropología se vuelve una valiosa disciplina que tiene un cometido ético y de gran responsabilidad frente a las sociedades que estudia. En esta búsqueda, ha surgido una suerte de antropología visual aplicada. Sarah Pink (2014) nos dice que la antropología visual aplicada se propone crear nuevas metodologías y prácticas para proyectos de intervención social que estén diseñados de acuerdo con las necesidades de las comunidades. Argumenta que la antropología visual aplicada puede enriquecer el desarrollo de la antropología visual y de la antropología aplicada como campos disciplinares de la antropología que pueden ser valorados transdisciplinariamente entre las ciencias sociales, pero también entre activistas, organizaciones no gubernamentales e incluso artistas interesados en encontrar innovadoras metodologías visuales para la investigación colaborativa y de intervención social.

Las metodologías aquí expuestas apelan a convertirse de alguna manera en experiencias de antropología visual aplicada, en la medida en que son diseñadas para el contexto de estudio y porque las relaciones de organización y colectividad surgidas en torno a estas prácticas catalizan y movilizan tanto al investigador como a los participantes.

En México, es dramático cómo se ha transformado la realidad del país. Lo que antes parecía libre de peligro, por ejemplo viajar y visitar diversas comunidades para hacer trabajo de campo, ahora ocurre en un panorama incierto. Como parte de mi experiencia formativa visité por algunos años consecutivos las costas michoacanas para hacer trabajo de campo en la comunidad campesina de Pómaro, y en cuestión de tres o cuatro años la comunidad nos pidió que dejáramos de visitarlos, porque las tensiones con el narcotráfico y el ejército eran cada vez mayores. A partir de ese momento Michoacán nunca volvió a ser lo que recuerdo, nunca pude regresar a Pómaro con esa seguridad que me brindaba la comunidad.

El trabajo cotidiano para cualquier antropólogo en la actualidad, y en particular siendo mujer, es en extremo riesgoso, incluso al acercarnos a los temas que parecerían más superfluos.

Esta situación de cambio acelerado genera un cuestionamiento respecto a las implicaciones que tiene la antropología y su quehacer sobre dicho panorama nacional. Desde una antropología comprometida, el investigador ya no únicamente se limita a describir una realidad; con su conocimiento y el de las sociedades con las que interactúa busca también incitar y propiciar la manera de concretar utopías de cambio y transformación que ayuden a resolver problemáticas o, por lo menos, contribuir a su esclarecimiento.

Si bien como antropólogos no tenemos una preparación para contener y enfrentar situaciones de alto riesgo, sí creo que podemos apelar a recursos que, desde la etnografía misma, nos ayuden a ser partícipes activos de nuestras propias etnografías, es decir, un contexto de violencia te obliga a dejar de ser observador para convertirte en actor, lo que conlleva sentirte muchas veces incluso más vulnerable que las personas en riesgo, por lo que esa distancia que antes se establecía entre antropólogo-comunidad de estudio se desdibuja. Nos volvemos cómplices y partícipes al estar expuestos a la misma situación de riesgo.

Hoy en día es casi imposible pensar hacer trabajo de campo de forma clásica o tradicional, debemos cuidar a nuestros interlocutores, incluso como institución académica. ¿Cómo acompañar entonces procesos sociales permeados de violencia? ¿Cómo poder acompañar la lucha de los familiares de desaparecidos? El arte textil y el cine documental han sido un camino efectivo para acompañar. Si bien el arte no cambia al mundo, sí cambia la forma en que lo miramos.

Justamente en este contexto, en el que el arte y el pensamiento son formas de colaboración, interesa la pregunta sobre qué implica plantear la construcción de "narrativas textuales y visuales que sanan", o de "elaborar colectivamente el duelo tras la experiencia traumática de la masacre", o la "elaboración del duelo social" [Diéguez y Perrée, 2018: 23].

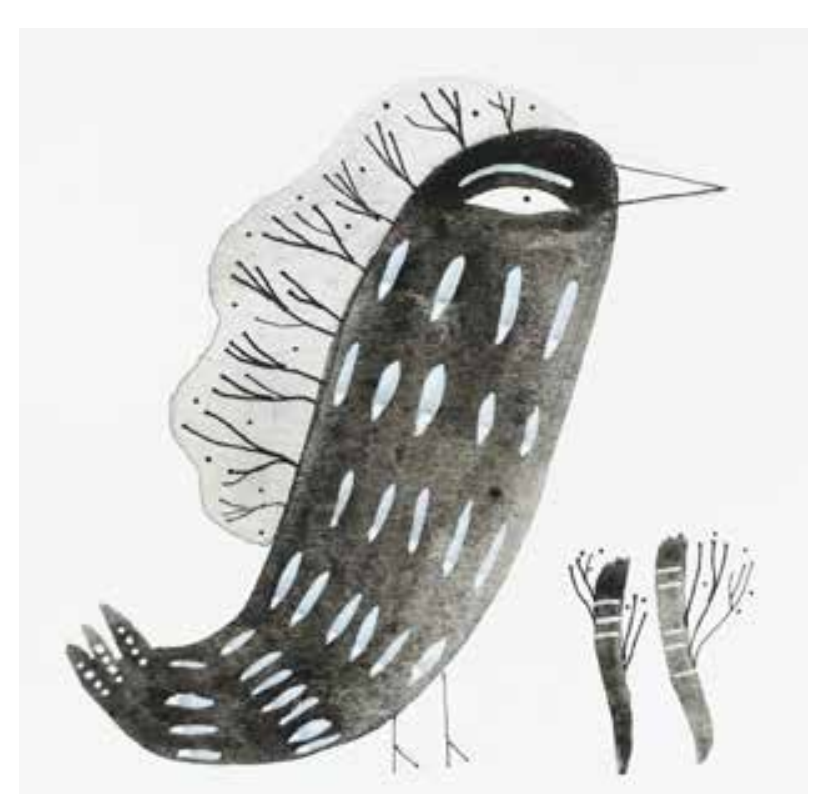


El documental y el tejido testimonial son formas de expresión y comunicación cuya base de creación está fuertemente arraigada a las esferas emocionales. Las emociones nos hacen actuar, movilizarnos y hasta organizarnos. Todas nuestras acciones y decisiones en la vida están motivadas por emociones. El arte en su diversidad de expresiones nos moviliza, por ello, todo quehacer etnográfico que implique conmover o dejarse conmover podrá garantizar la creación de comunidades emocionales organizadas y motivadas por un sentir común que los conecta y potencia.

\section{El quehacer textil y audiovisual: narrativas de la memoria}

$\mathrm{Al}$ introducirme como investigadora al campo de lo textil lo hice en primer lugar al asumirme como tejedora, condición que me ha facultado hacer una lectura más allá de las demandas académicas.

La práctica textil, aparentemente aislada y silenciosa, que ha sido parte de muchas generaciones de mujeres, ha tomado desde hace varios años una fuerza política y social sin precedentes. No es casual que el lenguaje de los hilos sea una forma de escritura tan poderosa para albergar, construir y significar la memoria (Arnold, 2006).

Lo que se teje se ha convertido en testimonios vivos de los tiempos de la guerra, de las injusticias y desigualdades. Estos tejidos y bordados testimoniales a manera de tapices tienen como antecedente el trabajo de las arpilleristas en Chile, que durante la dictadura de Augusto Pinochet (entre 1973 y 1989) generaron un movimiento textil en el cual bordaban escenas de violencia, desapariciones y asesinatos (Pérez Hernández y Viñolo Berenguel, 2010).

Para las mujeres que utilizan esta narrativa, la militancia textil que supone crear piezas testimoniales ha significado una forma de resistencia política, donde cada puntada es una denuncia, un reclamo por justicia y reparación. Llevar el tejido al espacio público como acto político -y más recientemente a los sitios institucionales de memoria como los museos- ha servido para reconocer el tejido como testimonio y documento.

Tejer es algo más que sólo habilidad y destreza para combinar y entrelazar hilos. Es la posibilidad de comunicar y crear significados a partir del tejidoescritura sobre diversos materiales.

El objeto tejido es un signo, y dentro del contexto sociocultural donde se le concibe y cumple con su función sígnica; es un lenguaje no verbal a través del cual se comprende la conexión que existe entre la naturaleza, el mito, el hombre, la sociedad y el objeto que como manifestación material integra su cuerpo y contenido para hacer parte de la vida cotidiana de la comunidad [Quiñones Aguilar, 2000: 80].

El textil en todas sus acepciones, ya sea en cuanto texto o mapa, como portador de mensajes, como la continuidad de la memoria y la identidad, como metáfora de la creación del universo, como modo de representar las relaciones humanas, o bien en su capacidad subversiva, puede leerse y considerarse un texto (Rivera García, 2017: 35).

Así, hay una profunda relación entre tejido y memoria, al ser el primero un repositorio de la segunda. El tejido como narrativa ha sido históricamente apropiado en la mayoría de los casos por mujeres, quienes han expresado con sus hilos la experiencia y el conocimiento femenino heredado por generaciones.

El tejido actúa como mecanismo mnemotécnico para recrear o recordar la sensación original de la experiencia. Generalmente la transmisión cultural ha sido a través de la oralidad, las fiestas y rituales, pero se podría considerar que existe una tradición o transmisión tejida y que a través de ésta se haya formado un sistema por el que se pudo aprender, recordar y conservar los diferentes elementos iconográficos [Ramírez Martínez, 2004: 3].

Aunque consta de procesos con ejecuciones variadas, tejer es una acción repetitiva, puntada tras puntada se acumulan los nudos que dan cuerpo a la tela. La repetición, igual que en cualquier ejercicio manual, es una forma de hacer memoria, de dejar un registro en el cuerpo. Todo lo que se repite queda en la memoria.

El tejido, que por mucho tiempo estuvo confinado al orden de lo privado, silencioso y solitario, es ahora una actividad propicia para realizarse en colectivo, estimulando el relato, la escucha y la organización comunitaria. En la actualidad, en los grupos de tejido en los que he podido participar, predomina un sentimiento de colectividad, apoyoy amistad entre las participantes. Son espacios donde se puede conversar, darse aliento y apoyo mientras se teje, es decir, donde los cuerpos son cobijados emocionalmente por las compañeras y por las telas que producen mientras esto ocurre. Tejer es un acto de cuidado hacia el cuerpo, la mente y las emociones "Ya no solo es el hilo entrando y saliendo de la tela, perforando y unificando, sino que es el sujeto saliendo y entrando del material, volviendo sobre sí mismo y anudándose" (Bello y Aranguren, 2020: 198).

Desde tiempos antiguos las mujeres dieron un sentido subversivo a su oficio, pues por lo general estaban 
alejadas de la alfabetización, recluidas en silencio y atadas a su tejido, así que "se sirvieron inteligentemente de él para comunicar y para expresarse explotando la casi universal relación entre tejido y escritura y/o voz" (Segarra, 2001: 215).

Para el siglo xix el bordado y la feminidad ya estaban conectados por completo, y, por ello las mujeres comienzan a cuestionar este papel socialmente designado y sientan un precedente a través de la conformación de grupos radicales que subvierten estas ideas.

La participación de las mujeres en el arte abrió una puerta de aceptación a la creatividad femenina y la transformación de los conceptos sobre los que se construyó la noción de arte.

El Movimiento Sufragista de Mujeres en 1911 en Inglaterra recurrió al bordado no sólo como una manera de transformar los conceptos y la función del arte, sino para cambiar las ideas sobre la feminidad y el ser mujer. Organizaron una huelga de hambre a la par que comenzaron a bordar pañuelos con sus firmas y así elevar la protesta de su petición política.

Más tarde, el eslogan del Movimiento de las Mujeres por la Liberación en Estados Unidos durante la década de 1960 era "the political is the personal", refiriéndose con esto a que sus demandas comenzaban desde lo personal, pero debían volcarse al ámbito público y político, afirmaban que la situación de opresión de la mujer en lo privado y doméstico era el reflejo de lo que sucedía a mayor escala en la sociedad, normado por las instituciones y las ideologías dominantes. El bordado, que representaba la actividad doméstica, podía lograr su propia liberación (Parker, 2010).

Esta actividad textil, que conocí en Colombia, rápidamente se replicó en México ante el acelerado crecimiento de la violencia. En poco tiempo los colectivos que denunciaban hechos atroces a través del textil eran cada vez más. Las metáforas referentes al tejido en estos contextos cobraron mayor sentido: remendar el tejido social, hilvanar la memoria, zurcir redes, crear nodos, cocer dolores, tejer empatía.

El tejido permite dar cuerpo al dolor. Se trata de nombrar, enunciar, legitimar y visibilizar, para que después la organización colectiva lleve el tejido a otros ámbitos de incidencia como sucedió en Colombia con los tapices tejidos que llegaron a los tribunales de justicia como testimonios de lo ocurrido y se volvieron herramientas de litigio en casos de violación de derechos humanos.

Durante los cuatro años de mi tesis doctoral pude realizar trabajo de campo entre tejedoras amuzgas en el estado de Guerrero e incentivé actividades de intercambio entre tejedoras de Colombia y México mediante exposiciones, realización de documentales, elaboración de talleres y una muestra de cine textil. De este modo, el vínculo con colectivos textiles de América Latina se amplió e interconectó. Durante todos estos años he documentado con mi cámara los talleres de tejido y memoria, así como realizado narrativas audiovisuales y experimentales y hasta autoetnográficos sobre mi propia historia como tejedora. He sentido tanta afinidad entre el tejido con hilos y el tejido con imágenes que incluso cofundé un colectivo audiovisual que se llama Urdimbre Audiovisual, con la finalidad de explorar sensorial y etnográficamente con ambas narrativas que, como ya mencioné, se interconectan como metodologías y procesos de comunicación. El impacto y la difusión que tiene el audiovisual es sustantivo, y es algo que en las comunidades con las que me ha sido posible hacer investigación han podido notar.

Después de la experiencia de investigación en torno al tejido y la memoria en Colombia y en el estado de Guerrero con tejedoras amuzgas, fui invitada a Morelia, Michoacán por mi colega Bianca Islas para impartir juntas un taller de transferencia de imágenes fotográficas sobre tela para después ser intervenidas con bordado. En este contexto conocí al colectivo llamado en ese entonces Familiares Caminando por Justicia, constituido sobre todo por mujeres organizadas en busca de sus desaparecidos. Tomaron el taller con la intención de transferir las fotografías de sus seres queridos, pero les sugerimos que primero transfirieran una fotografía donde ellas aparecieran. Esta actividad un poco inesperada de autorrepresentación con la imagen propia posibilitó un momento emotivo y colectivo, pues mientras revelaban la imagen propia sobre la tela y luego entre puntadas se bordaban, platicaban con mucha confianza sobre sí mismas, de sus dolores y sus esperanzas.

A partir del taller fuimos tejiendo una amistad cercana y decidimos junto con ellas documentar en video sus experiencias e historias en torno al proceso de desaparición y búsqueda. En un inicio lo que nos interesaba documentar era la relación con el tejido y el bordado, pero poco a poco fueron surgiendo otros aspectos vinculados con su vida cotidiana que también era necesario documentar.

¿Por qué el registro audiovisual se vuelve el dispositivo y lenguaje para este fin? Primero porque de manera personal siento afinidad con este recurso, el cual me permite la documentación sensible y cercana de la realidad. La cámara ha sido un instrumento para mirar a estas mujeres con un compromiso mayor, enfocarlas con dignidad y respeto para compartir una indignación común frente a esta terrible situación. También es una forma de devolver con cariño y sinceridad un retrato, una visión propia y a la vez 
colectiva de todo lo que uno aprende y lo que otros nos develan a través del lente para comprender de mejor modo su realidad.

El registro audiovisual, al igual que el tejido, son actividades que implican poner el cuerpo en la práctica, hacerse una con el tejido y tejer; hacerse una con la cámara y retratar desde la emoción de lo que se quiere transmitir. "Poner el cuerpo en la investigación es situarse en un sentido literal, es colocarse, descolocarse, moverse, llegar al límite y conocer desde cada uno de estos estadios" (Ramírez Morales, 2021: 222).

El cine, además de ser una práctica colectiva, requiere de sensibilidad para posicionar la mirada, activar la escucha para registrar con oportunidad los eventos y las relaciones de las personas con su entorno.

La producción de imágenes ha sido por mucho tiempo una cuestión de privilegio que demuestra una relación de poder entre quien retrata y el retratado, sin embargo, en tiempos recientes, dada la posibilidad cada vez más generalizada de acceder a un dispositivo electrónico como un celular que cuenta con una cámara, se facilita hasta cierto punto la producción visual local, empero, no por fuerza se implementa con un objetivo narrativo. Aun así, para una gran parte de la población en México, el acceso a dispositivos electrónicos es limitado. Es por ello que los relatos audiovisuales que los antropólogos o cineastas producimos en contextos como los de la desaparición forzada, en colaboración o complicidad con los actores sociales, son altamente valorados por ellos. De alguna manera se hace justicia, al menos con sus imágenes y sus voces; los relatos que nos comparten se vuelven testimonios que perduran en el tiempo.

¿Para qué documentar estas historias? Primero porque es una forma de devolver la dignidad a quienes les ha sido arrebatada en actos violentos y cobardes; segundo, porque el registro guarda la huella de los acontecimientos, nos permite documentar experiencias concretas con minuciosidad y con una amplia investigación; además posibilita dar a conocer realidades complejas, y comprender mejor lo que atraviesan las personas que han sido tocadas por la violencia. "Grabar el dolor es una prueba de que este drama existió, aunque no se haya hecho justicia. Es una lucha contra el olvido, contra la desaparición" (Bonleux, 2018: 152). La cámara invita a observar de un modo particular la realidad.

El trabajo documental conlleva, al igual que la etnografía, un alto compromiso ético y mucho tiempo de acompañamiento para que los eventos vayan sucediendo frente a la cámara a su tiempo y ritmo. Se requiere saber esperar, pero también ser perceptivo e intuitivo. Conforme el antropólogo conoce mejor el contexto, desarrolla su intuición y sensibilidad que favorece registrar de mejor modo el medio que está investigando. Realizar el acompañamiento audiovisual a las familiares de desaparecidos implicó llevar el cuerpo y la cámara a la situación que el relato demanda, aun si esto suponía acompañar a las protagonistas al campo donde se encuentra el riesgo.

La cámara, como una extensión de mi cuerpo, me ha permitido retratar, dialogar, colaborar y difundir estas experiencias que, en mayor o menor grado de riesgo frente a los contextos que voy a relatar, ha significado para mi quehacer antropológico un apoyo técnico y teórico que me ha dado la oportunidad de observar, interpretar y representar una realidad de manera enriquecida.

La sistematización teórica de las posibilidades que los medios audiovisuales brindan a la investigación etnográfica ha sido tema para los antropólogos visuales, pues la disciplina no sólo se enfoca en la producción audiovisual y su análisis, sino en la creación de dispositivos narrativos que exploren en lo sensorial, en cómo comunicar y generar conocimiento que verdaderamente apoye la narrativa de los afectados por la violencia. Esto es muy importante tanto para el caso textil como para lo audiovisual, ya que como creadoras/mediadoras/investigadoras podemos devolver sus testimonios y procesos, además de generar una representación digna de quienes acompañamos, lo que significa sacarlas de la victimización para dar lugar a su representación en cuanto artistas-creadoras con una agencia y poder de acción. "Reconocerse como artesanas y hacer de su oficio textil una práctica que reordena el ritmo cotidiano, así como los lazos comunitarios y solidarios entre mujeres, ofrecen otros marcos subjetivos que no se limitan a la representación como víctimas o a la espera de la reparación" (Quiceno Toro y Villamizar Gelves, 2020: 132).

\section{Acompañamiento audiovisual y textil a la v Caravana de Búsqueda de Personas Desaparecidas en Michoacán}

"YYa no tengo miedo a morir!", claman las madres de desaparecidos en México. Esta afirmación deja muy claro que cuando ya se ha pasado por tanto sufrimiento y desesperanza nada puede detener a estas mujeres.

La desaparición forzada en México se nombra como tal desde los años sesenta y setenta durante la guerra sucia, y surge como una estrategia sistemática de represión implementada por el Estado mexicano para erradicar la disidencia política. El creciente interés 
académico por investigar y estudiar a fondo esta temática en la actualidad está permeado por la desenfrenada ola de violencia y los cada vez más frecuentes casos de desaparición en todo México, en particular en zonas rurales, campesinas e indígenas con alto grado de marginalidad y pobreza, donde los grupos criminales ejercen su poder y control, dando lugar a uno de los más grandes negocios delictivos en el cual se involucra la trata de personas, el trabajo esclavizado, las extorsiones, los despojos, entre otros. "La desaparición no es únicamente un crimen mediante el cual se priva de la libertad a alguien, sino también es una práctica social de exclusión propia de las sociedades liberales que condena a poblaciones enteras a la clandestinidad, el borramiento y la inexistencia social" (Robledo-Silvestre y Querales-Mendoza, 2020: 7).

Esta abrupta escalada de violencia puede entenderse coyunturalmente a partir de la declarada guerra contra el narcotráfico en 2006. Años después, el 26 de septiembre del 2014 ocurrió la desaparición de los 43 normalistas de Ayotzinapa, evento que sería un parteaguas respecto a la creciente organización de familiares de desaparecidos en el país. "La cuestión de la desaparición forzada de personas en México salió abruptamente a la luz, se ha vuelto un leitmotiv, y la búsqueda, una necesidad y una obsesión" (Diéguez y Perrée, 2018: 11).
Suman "61 mil 637 personas desaparecidas, 97 por ciento de las cuales son de 2006 a la fecha y el resto entre ese año y 1964" (Enciso, 2020). En la actualidad las desapariciones ocurren en un contexto mucho más complejo que el de la guerra sucia, no tenemos un escenario claro donde podamos entender las tensiones y disputas particulares donde se dan estas desapariciones.

Los regímenes de violencia en el país donde se insertan los distintos contextos y motores de la desaparición contemporánea están regionalizados a nivel local y las dinámicas específicas de cada lugar contribuyen a que se produzca y reproduzca la violencia, pero también esto determina que se articulen ciertos movimientos para abatirlo.

Frente a este brutal escenario, cada vez más cotidiano, las distintas disciplinas académicas tanto de las ciencias sociales como exactas, en conjunto con actores de la sociedad civil organizada, medios de comunicación y los familiares de las personas desaparecidas o asesinadas, han sumado esfuerzos en la búsqueda de justicia y reparación. En este sentido, podemos decir que éste es uno de los aspectos positivos, el poder estrechar vínculos entre disciplinas y actores sociales, y fortalecer proyectos colaborativos. Por lo que hoy tenemos una academia más sensible y cercana a esta problemática.

Foto 2

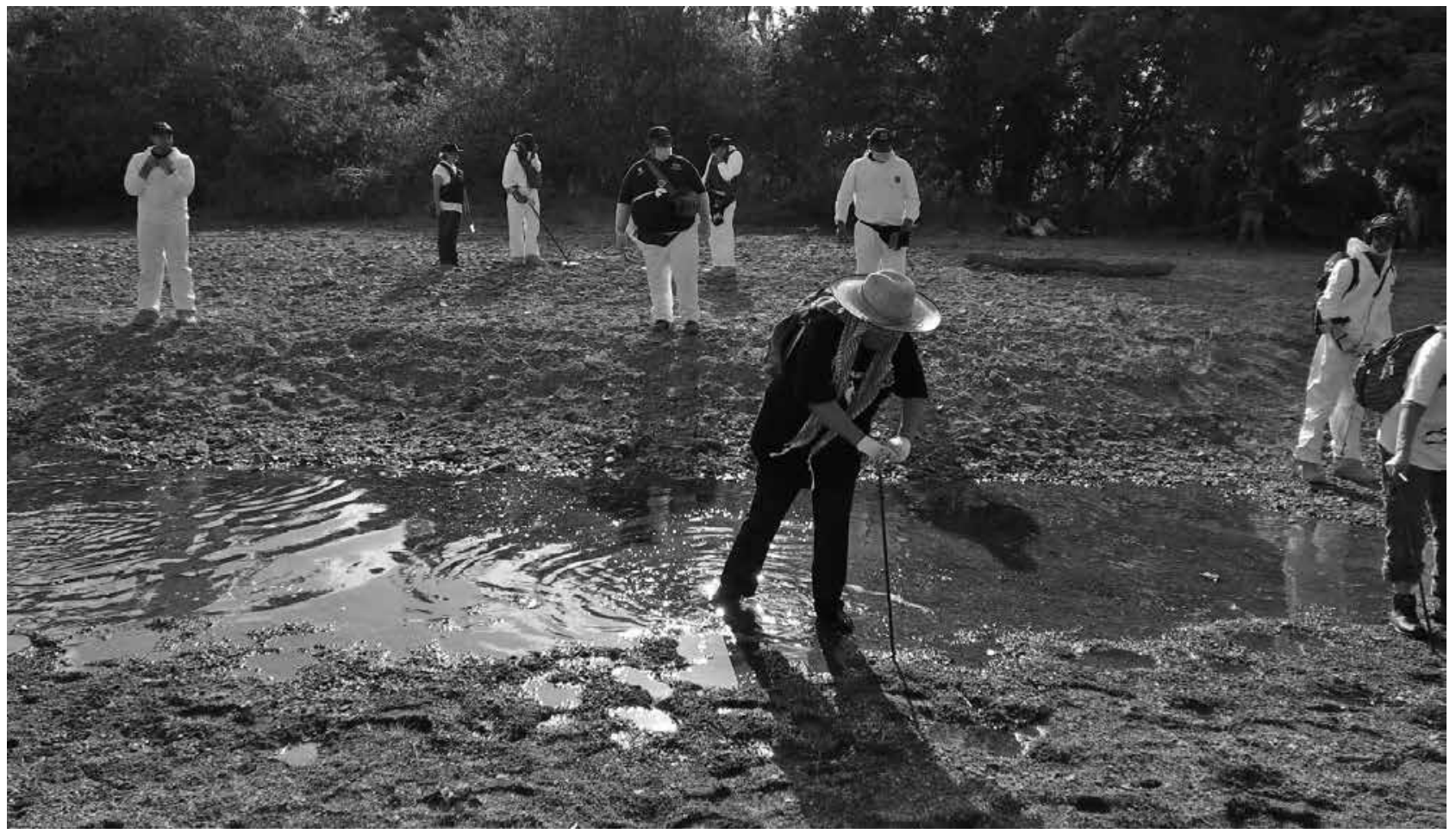

Buscando en el río. V Caravana de Búsqueda de Desaparecidos en Michoacán (foto: Mariana Rivera). 
No es el objetivo de este texto entrar en detalles históricos sobre la desaparición forzada en Michoacán, me enfocaré simplemente en trazar la ruta en la cual los hilos y el tejido me fueron uniendo a esta problemática que afronta un grupo de mujeres michoacanas que buscan a sus desaparecidos. Asimismo, me adentraré en la reflexión antropológica centrada en las implicaciones de hacer trabajo de campo en estos contextos.

En mayo del 2019 se organizó la V Caravana de Búsqueda de Personas Desaparecidas en el estado de Michoacán, las mujeres de quienes hemos hablado fueron las anfitrionas y organizadoras principales de esta caravana, la cual se llevó a cabo del 29 de abril al 12 de mayo recorriendo el Servicio Médico Forense (Semefo), centros de readaptación social (Ceresos), hospitales y, por primera vez, realizando la apertura de fosas clandestinas en la costa michoacana. Se recorrieron las localidades de Sahuayo, Zitácuaro, Huetamo y Caleta de Campos.

Previamente, en el 2018, estas mujeres tomaron el taller Búsqueda, localización y registro de hallazgos humanos contemporáneos en contexto legal, impartido por un grupo de antropólogas físicas, el cual también tuve la oportunidad de tomar y documentar.

La caravana se conformó por organizaciones de familiares de desaparecidos de los estados de Veracruz, Guerrero, Coahuila, Nuevo León, Morelos, y hasta un grupo de personas que acompañaron desde Ecuador.

Uno de los objetivos de la caravana era documentar nuevos casos de desaparición que la gente de las localidades visitadas quisiera registrar y comenzar a dar seguimiento.

Supuestamente, la caravana debía contar con la seguridad de la policía del estado, así como la Guardia Nacional, cosa que no ocurrió en muchos tramos carreteros, donde la caravana fue dejada a su suerte en territorio en extremo peligroso.

Además de los camiones que transportaban a los familiares de desaparecidos, el contingente estaba conformado por los peritos ministeriales y una ambulancia, también acompañábamos una camioneta de periodistas y nuestro vehículo (en el que íbamos mi colega Bianca Islas y mi compañero Josué Vergara), como equipo de documentación audiovisual. De igual modo, algunos días estuvo un representante de derechos humanos y el responsable de la Comisión Ejecutiva Estatal de Atención a Víctimas (CEEAv).

En este texto no hay espacio para contar los pormenores de la experiencia, pero intentaré relatar algunos momentos de vulnerabilidad como investigadora en campo, así como reflexionar sobre ciertas ocasiones que documenté con mi cámara, relativos a las dis- tintas discriminaciones a las que fueron sometidas las mujeres como organizadoras, demeritando que su conocimiento sobre el territorio era de suma importancia para la seguridad de la caravana.

Cuando hablamos de familiares de desaparecidos no nos referimos a una categoría homogénea, pues hay grandes diferencias entre familiares según su condición económica, conocimiento y relación con las autoridades institucionales, lugar de procedencia, incluso la condición de género crea una situación muy diferenciada entre hombres y mujeres.

En primer lugar, las mujeres de Michoacán a cargo de la caravana eran muy pocas para todo el trabajo de organización que debía realizarse (rutas, hospedaje, alimentación, transporte, seguridad, enlace con informantes, medios de comunicación, documentación, equipo, herramienta de trabajo). En segundo lugar, tienen poca experiencia en búsqueda en campo, pues, como ya mencioné, nunca antes se habían abierto fosas en el estado de Michoacán, por lo que esta actividad era algo nuevo para ellas. Por último, el grupo venía desgastado por todo el trabajo y gestiones que significó la organización de la caravana, lo cual generó malentendidos y en ocasiones disgusto y frustración entre ellas y con otros familiares.

En este contexto nos sumamos a la caravana, pero jamás imaginamos el nivel de inseguridad del trayecto y tampoco fuimos consientes de las discrepancias entre los colectivos de familiares que tienen formas muy distintas de operar. Lo primero que notamos fue el protagonismo de uno de los familiares que venían del norte, cuya experiencia en búsqueda era notablemente mayor y quien posee un conocimiento amplio de cómo tratar con las autoridades. Las decisiones tomadas de manera arbitraria por este sujeto en nombre de su experiencia, iban en contra de todas las decisiones que las mujeres michoacanas tomaban en función de las actividades ya planificadas, dado que ellas conocen mejor que nadie su territorio. El protagonismo y la imposición constante de este sujeto por encima de las anfitrionas era evidente y todo el tiempo provocó mucha discordia.

El primer sentimiento de vulnerabilidad en este ambiente lo sentí la primera noche durante la cena, cuando la vocera de un colectivo decretó que quienes veníamos como acompañantes junto con los periodistas ocupábamos el último lugar de prioridades, lo que en términos de seguridad significa que, si tocaba sacrificar o salvar a alguien de una situación de riesgo, no seríamos los primeros en la lista. Este sentimiento poco solidario hacia quienes acompañamos y nos arriesgamos sin tener un familiar desaparecido fue el primer escalofrío al pensar que una está descobijada. 
Sentí que poner el cuerpo y nuestra vida en dicha misión era poco valorado por quien afirmó esto. Esta sensación fue cambiando con los días y conforme fuimos conociendo mejor a aquellos otros familiares y, de hecho, las mujeres de Michoacán -a quienes realmente acompañábamos- siempre nos hicieron sentir parte del colectivo, sin importar lo que los otros familiares dijeran.

El día que salimos a la búsqueda en la primera fosa en Caleta sufrimos intimidación por un par de jóvenes en motocicleta que venían siguiéndonos en la carretera. Uno de ellos nos mostró un arma cuerno de chivo. El camión de familiares que encabezaba la caravana frenó abruptamente mientras uno de los coches de policías detenía a los jóvenes en moto. El segundo camión estuvo desaparecido por largos minutos y tampoco contestaban las radios. El ambiente se puso tenso, la coordinadora del primer autobús se acercó a la camioneta para decirnos que sospechaba que el otro camión había sido emboscado. Mientras tanto los policías les quitaban el arma a los jóvenes de la moto, ahí se dieron cuenta de que era un arma de plástico, quizá fabricada con una impresora 3D. Los chicos de la moto con aspecto de halcones se alejaron en la moto con mirada retadora. Sentimos que la sangre se nos helaba. Los militares que nos acompañaban dijeron que en efecto eran halcones y que tenían la misión de amedrentarnos, que ellos venían escuchando en la interferencia de sus radios cómo iban dando información sobre nuestro recorrido, también nos comentaron que con seguridad esos dos jóvenes serían asesinados porque no habían logrado infundirnos miedo y porque el arma les había sido confiscada. Al poco tiempo apareció el segundo camión de familiares y un poco más aliviados pudimos continuar hasta la fosa donde más tarde se encontrarían 43 restos óseos y casquillos de bala.

En los poblados visitados, la gente nos veía con timidez, muchas veces ni nos sostenían la mirada. Algunos confesaron que era miedo lo que hacía que nadie denunciara, sin embargo, hay varios municipios donde casi todos los habitantes tienen por lo menos un desaparecido.

Durante los cinco días que permanecimos en Caleta realizando actividades de búsqueda, la caravana se hospedó en las instalaciones de la parroquia del poblado, no obstante, conforme los días pasaban sentíamos cada vez mayor hostigamiento por parte de convoyes de camionetas con sujetos armados que se instalaban en la esquina de la parroquia a tomarnos fotografías.

Foto 3

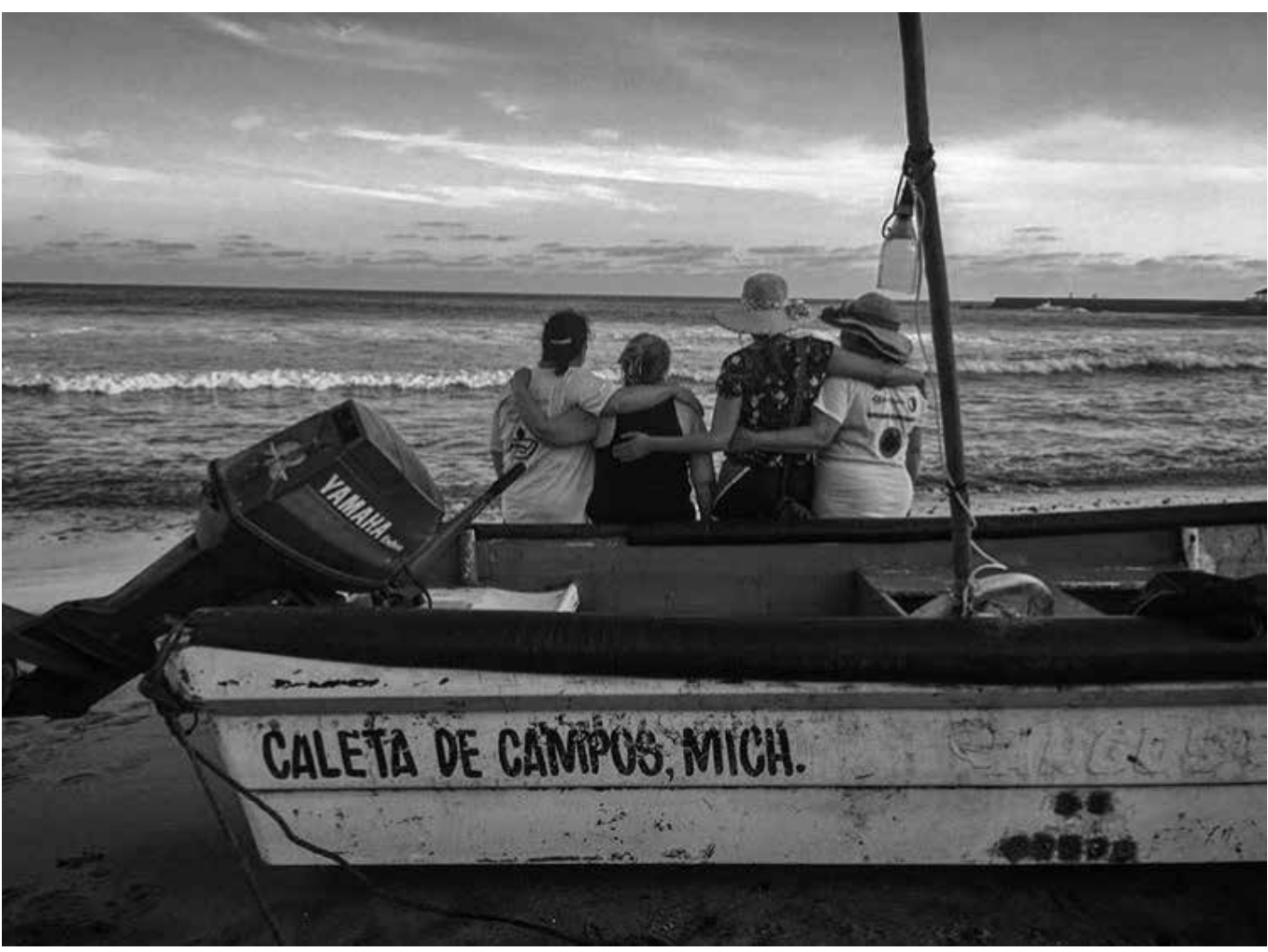

¿Qué le dirían al mar?. Familiares caminando por Justicia (foto: Mariana Rivera). 
El 10 de mayo, cuando se acercaba el fin de la caravana, se decidió realizar un acto político por el Día de las Madres en la kiosko principal de Caleta, el padre de la iglesia ofreció una misa y los familiares tapizaron con lonas y fotografías la plaza principal. Con anterioridad se había determinado hacer una pequeña marcha por el pueblo antes de arribar al kiosko. La marcha la encabezaban, por su puesto, las madres michoacanas, y ya se había trazado una ruta, no obstante, de última hora, el sujeto conflictivo que mencioné, decidió modificar la ruta, y como las madres de Michoacán venían al frente y no habían sido notificadas de este cambio, de pronto se vieron solas caminando por la calle "equivocada", es decir, la caravana se fue por otro lado, dejando a estas mujeres sin seguridad en la zona más peligrosa, donde una de ellas ha sido amenazada de muerte en múltiples ocasiones. Ellas enfurecidas siguieron su camino original hasta que el representante de la CEEAv las alcanzó, yo con mi cámara pude grabar este enfrentamiento y después los de la CEEAv y la organización a la que pertenece este sujeto me pidieron que por favor borrara ese grave incidente documentado, evidentemente yo no lo borré en un acto de solidaridad con las compañeras de Michoacán. Cuando arribamos al kiosko, se impartió la misa y al poco tiempo notamos que estábamos rodeados por sujetos armados que sólo se paseaban mirándonos, tuvimos que suspender la actividad y volver a nuestro refugio en la parroquia, donde ya también nos sentíamos amenazados.

Cuando faltaba un día para finalizar la caravana, se tenía establecido que el regreso sería el domingo por la mañana para evitar pasar de noche por la zona de la carretera donde se encuentran laboratorios del narcotráfico, no obstante, sin previo aviso, el mismo sujeto conflictivo decidió que él se quería regresar el sábado, de noche y por donde ya se había acordado no transitar. De improviso sometió a votación esta cuestión del regreso, por desgracia, como muchos lo consideran una figura de autoridad, votaron para apoyar su propuesta. Las mujeres anfitrionas estaban muy molestas y preocupadas, nosotros que veníamos en un vehículo aparte también nos comenzamos a angustiar con la simple idea de volver cansados y manejando de noche por aquella carretera, por lo que optamos por no arriesgarnos y resolvimos salir un día antes, lo cual implicaba separarnos de la caravana y emprender el camino por nuestra cuenta. Un par de mujeres de otros colectivos nos pidieron si podían irse con nosotros de vuelta, pues tampoco querían arriesgarse a la voluntad de este señor, accedimos a ir juntos. El trayecto de unas cuatro horas de Caleta a Lázaro Cárdenas y luego a Morelia fue de mucha angustia.
Los primeros kilómetros de nuestra salida de Caleta fuimos seguidos por una camioneta con dos sujetos armados. Nos deshicimos de ellos después de Lázaro Cárdenas, donde por fin nos rebasaron, no sin antes dirigir su mirada retadora ante nosotros.

Tardé muchos días, quizá meses, en poder procesar todas las emociones y vivencias, reflexionando que, en definitiva, uno nunca está lo suficientemente preparado para un trabajo de campo de este tipo; con todo, haber logrado salir con vida y tener en resguardo el material audiovisual se convierte en un documento de gran valor testimonial para el presente y el futuro. A partir de esta experiencia durante la caravana puedo resumir lo siguiente:

- Hay un fuerte machismo y discriminación entre las organizaciones de familiares de desaparecidos, donde entra en juego el nivel socioeconómico y por supuesto el capital cultural de las víctimas, que repercute en el acceso diferenciado a los servicios de impartición de justicia.

- No cabe duda de que la seguridad para llevar a cabo las actividades de búsqueda está ausente en la mayoría de los casos, pues su garantía se vuelve una cuestión de privilegios.

- Pudimos ser cómplices de la implicación que tiene el Estado en el "performance" de este tipo de búsquedas, donde las instituciones están informadas e incluso en teoría colaboran con dichas actividades. Empero, constatamos que el fiscal del estado michoacano apareció un solo día durante la búsqueda en uno de los lugares donde era evidente que no encontraríamos nada, fue a tomarse la foto con los peritos, acompañado de un comando fuertemente armado, a decirnos que Michoacán era un estado pacífico donde no había violencia. Se despidió con una amenaza: "Está fuerte el sol ¿verdad?, aprovechen porque no siempre hay", sentenció.

- El desgaste y el cansancio que padecen las familias durante los procesos de búsqueda son abrumadores, muchas veces innecesarios, lo que los lleva a experimentar frustración constante y afectaciones a su salud.

- En este breve tiempo compartido en la comunidad de la costa michoacana, uno puede evidenciar que el futuro de los jóvenes que nacen y crecen en este contexto es el de convertirse en sicarios, halcones, narcotraficantes y delincuentes. Los jóvenes no tienen más alternativas, son amenazados si no se unen al sicariato. A muchas familias no les queda más remedio que salir desplazados por esta violencia. 
El material que grabamos a lo largo de los días resulta de gran valor testimonial y como registro de experiencias que ponen de manifiesto la compleja situación que viven las organizaciones de familiares de desaparecidos en México. Este material no ha podido salir a la luz ni ha sido parte de un relato más estructurado por falta de consenso y diferencias entre las familias y personas que aparecen retratadas. No obstante, comparto aquí un link con contraseña donde se puede ver parte de este material y las situaciones que he descrito. ${ }^{1}$

Grabar procesos y experiencias derivados de la violencia es una forma -aunque arriesgada- de contribuir, apoyar, documentar un momento a un grupo de personas, escucharlas y acompañar su lucha. Aunque grabar circunstancias nunca le ha devuelto la vida a nadie, al menos ayuda a devolver la esperanza, y a exponer la trascendencia que tiene para la gente ser escuchada, sentir que su vida importa, que sus emociones, sentimientos y experiencias de vida son relevantes para la sociedad, aunque las autoridades quieran negarlas.
En un contexto donde el silencio se vuelve angustiante, visibilizar es quizás una primera acción para combatir el olvido colectivo, porque a través del relato y la acción se inicia un proceso de memorización pública, necesario en una sociedad que esconde sus males y sus muertos, carente de interlocutores confiables a quien recurrir [Diéguez y Perrée, 2018: 12].

\section{Reflexiones finales: asumirnos vulnerables}

Los resultados finales de la búsqueda en la caravana fueron los siguientes: “ 17 casos de 'posibles positivos', de los cuales 11 fueron documentados en el municipio de Zitácuaro, tres en Sahuayo, dos en Huetamo y uno en Los Reyes. Se registraron, además, 40 casos nuevos de desaparición a los cuales dará seguimiento el colectivo anfitrión" (Caballero y Paredes, 2019). Las consecuencias de la caravana fueron catastróficas: una semana después de finalizada, la compañera Zenaida Pulido de Michoacán fue asesinada.

\section{Foto 4}

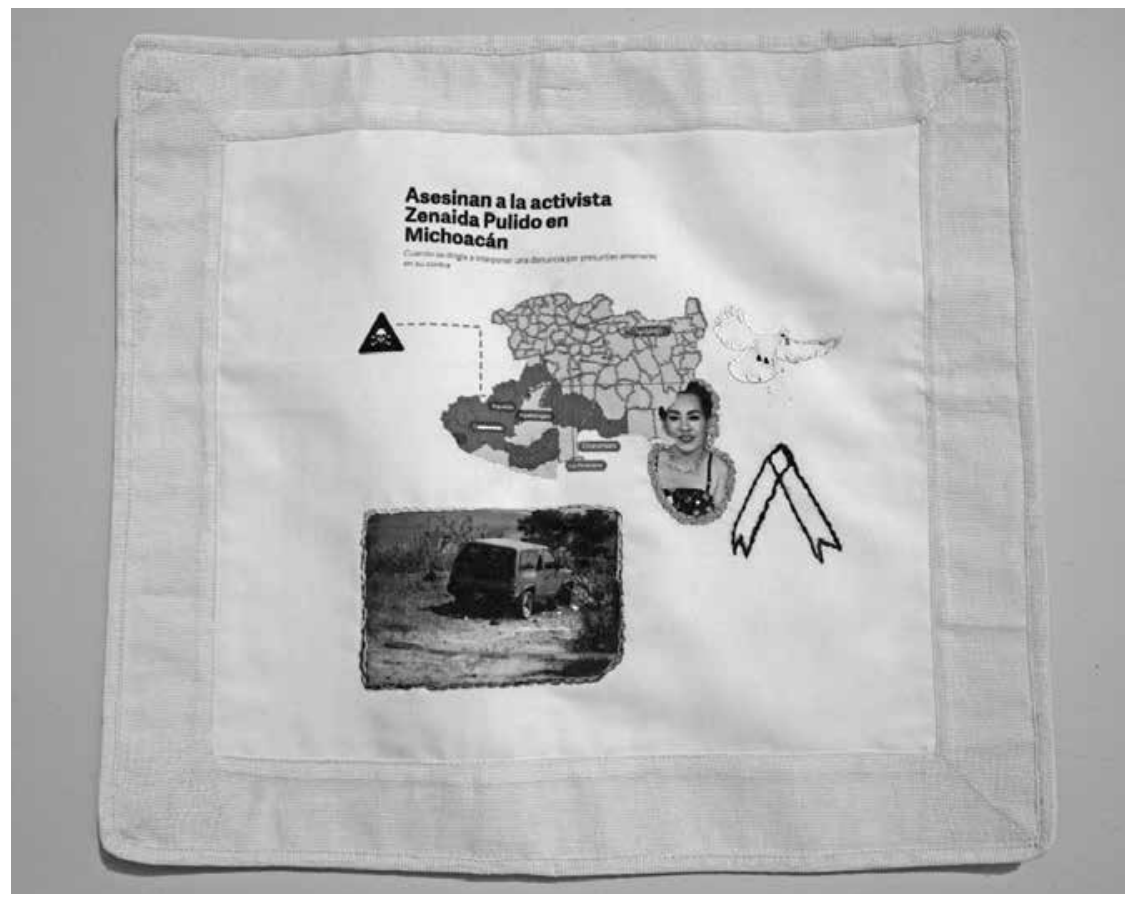

Asesinan a la activista Zenaida Pulido

Transferencia sobre tela y bordado del colectivo ¿Dónde están los desaparecidos? (foto: Bianca Islas).

\footnotetext{
1 <https://vimeo.com/575001324/> contraseña: caravanamichoacan
}

Se pide discreción al lector y sólo utilizar este material como complemento al texto escrito. De ningún modo es un discurso documental trabajado, sino un collage de situaciones documentadas cuya reproducción no está autorizada bajo ninguna circunstancia. 


\section{Foto 5}

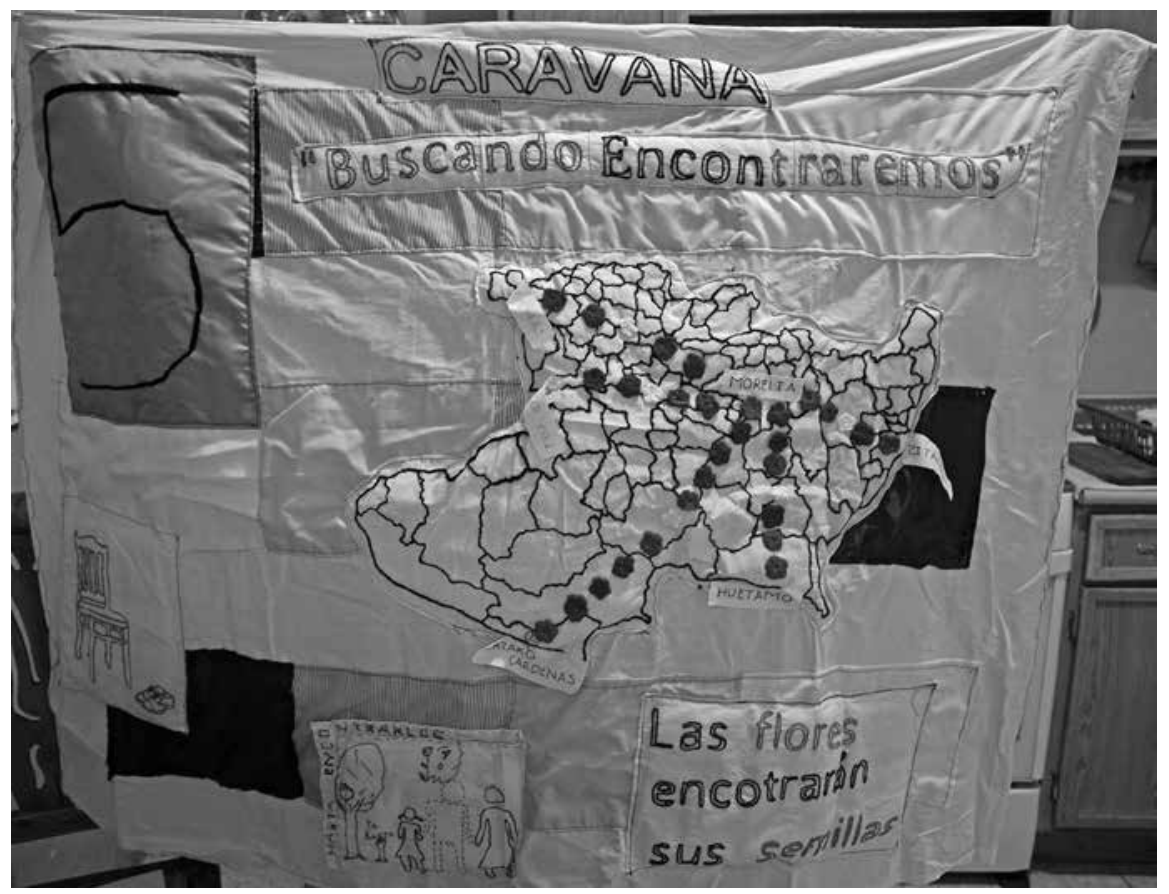

Cartografía textil Caravana. Buscando Encontraremos

Bordado por el colectivo ¿Dónde están los desaparecidos? (foto: Bianca Islas).

Por otro lado, la organización Familiares Caminando por Justicia se dividió y se formó el nuevo grupo ¿Dónde están los desaparecidos?, conformado por la mitad de las integrantes del colectivo que documentábamos.

Las intervenciones y prácticas textiles continuaron en ambos casos. La foto 5 muestra una cartografía textil elaborada a partir de la sistematización de la información obtenida durante la caravana, e incluye el mapa del estado y los puntos recorridos.

Esta experiencia me sembró muchas preguntas e inquietudes y me vulneró emocionalmente.

Por lo general, al situarnos como científicos sociales, tendemos a mirar las realidades que estudiamos con una mirada ajena, como queriendo acercarnos a una "objetividad", sin embargo, estas circunstancias nos ubican como actores incluso más vulnerables que los mismos familiares de desaparecidos, pues al menos ellos están organizados y con el tiempo y la experiencia saben que el miedo no es una limitante, se llenan de valor para afrontar las consecuencias que la búsqueda les depare.

En nuestro caso, que no vamos tras un familiar desaparecido, nos confronta: ¿Qué pasaría si los desaparecidos terminamos siendo nosotros? ¿Quisiera que mis familiares o amigos se vean envueltos en una situación como la que vivimos para ir en nuestra búsqueda? Estas preguntas me abstraen del discurso científico para pensar en el sentido humano que atra- viesa toda investigación: el cuerpo. El cuerpo como territorio donde experimentamos y significamos el trabajo de campo y por donde atraviesa la narrativa etnográfica, es decir, el lugar de la experiencia donde surge y se albergan las emociones. En el caso aquí presentado hablamos del cuerpo en riesgo como investigadora y los cuerpos de las mujeres buscadoras que están en permanente riesgo, pero también del trabajo etnográfico textil y audiovisual que atraviesan el cuerpo como medio de conocimiento y forma de relacionarnos.

A lo largo del artículo señalé que esta práctica de investigación antropológica, donde implementé procesos textiles y procesos de creación audiovisual en su forma metodológica, dio pie a pensar formas de abordar y afrontar contextos y temas de investigación relacionados con la violencia, donde la creación y la creatividad han sido motores para generar procesos comunitarios en sociedades marcadas por el dolor, pero también para incitar formas de organización social a través de narrativas poéticas en sus formas visuales, sonoras, gráficas y plásticas que permitan la difusión a un público amplio, así como generar reflexión ante las injusticias y desigualdades.

El vínculo de las prácticas artísticas, como el tejido y el bordado con fines testimoniales, aplicadas en contextos de violencia privilegia los procesos y los significa en el cuerpo donde la práctica representa nuestras emociones, nos permite estructurar de mejor manera 
el pensamiento, brindando elementos comunicativos y expresivos que ayudan no sólo a aminorar la pena, sino a generar vínculos sociales y alianzas de acompañamiento y empatía que son fundamentales cuando se experimenta miedo y violencia extrema.

Por otro lado, el recurso del cine documental como narrativa, que trasciende el registro, hace posible que estos relatos tengan cabida en espacios y entornos muy distintos a los de su producción, incluso pueden llegar a tener una incidencia positiva en el llamado de atención a las autoridades correspondientes para que realicen su trabajo, así como generar vínculos con otras organizaciones civiles que comparten problemáticas similares.

Con todo lo expuesto no pretendo dar respuestas precisas e incuestionables sobre lo que es hacer etnografía en contextos de violencia. La violencia siempre es cambiante y adversa ¿Cuál es entonces nuestra labor como antropólogos en estos contextos?

Según mi experiencia puedo concluir que:

- Las prácticas textiles como narrativas testimoniales transforman a las mujeres de víctimas en creadoras.

- El recurso de la grabación en video de los procesos, vivencias, testimonios y experiencias es una forma de documentar como sociedad civil.

- Ante este sombrío panorama me parece fundamental crear poéticas con la memoria y la narrativa antropológica.

- El antropólogo es un actor que puede fácilmente colaborar para generar puentes, lazos, cruces, puntos de unión y horizontes comunes entre la investigación, los protagonistas, las instancias educativas, las instituciones políticas y las organizaciones.

- Cada vez es más necesario prepararnos en otras disciplinas (cine, teatro, textil, psicología, derecho, antropología física, arqueología) para posicionar nuestras investigaciones desde diversas perspectivas y abordajes, además de enriquecer metodologías, herramientas e instrumentos útiles para tener más recursos con los cuales afrontar situaciones de riesgo o violencia.

- Es esencial definir los objetivos de la investigación, ¿a quién queremos llegar? A los medios, a los colegas, a las autoridades, a las víctimas. Esto determinará el camino y la narrativa adecuada que ayude a traducir la investigación de un lenguaje académico al lenguaje de lo sensible.

- Se requiere preguntarnos: qué tan profundo quiero llegar en una investigación; con qué elementos cuento para salvaguardar mi integridad y la de quienes nos rodean; ¿soy capaz de afrontar las consecuencias?

El tejido y el audiovisual fueron hilos compañeros para tejer la trama etnográfica durante la caravana de búsqueda de personas desaparecidas. Las características de estas prácticas propiciaron una mirada sensible, íntima y emocional que crea lazos, que involucra lenguajes y que nos cuestiona todo el tiempo sobre nuestro oficio. Para mí, la finalidad es unir, pegar, coser y transformar materialmente nuestras relaciones sociales dentro y fuera del campo, de forma tal que poner el cuerpo en riesgo tenga un sentido.

\section{Fuentes}

Ardévol, ElisendA

2008 "Cine etnográfico: relato, discurso y teoría", en Jordi Grau et al., El medio audiovisual como herramienta de investigación social, $\mathrm{CIDOB}$ Edicions (Dinámicas interculturales 12), Barcelona, pp. 31-50.

Arnold, Denise Y.

2006 "Ensayo sobre los orígenes del textil andino: cómo la gente se ha convertido en tela", en Denise Y. Arnold, Juan de Dios Yapita y Elvira Espejo Ayca, Hilos sueltos: Los Andes desde el textil. Plural editores/Instituto de Len-

Bello, AndReA gua y Cultura Aymara, La Paz, pp. 49-80.

y Juan Pablo Aranguren

2020 "Voces de hilo y aguja: construcciones de sentidoy gestión emocional por medio de prácticas textiles en el conflicto armado colombiano", en H-ART. Revista de Historia. Teoría y crítica de arte, núm. 6, enero-junio, pp. 181-204.

Bonleux, Ludovic

2018 "Documentar lo(s) olvidado(s): entre registro de lo ausente y resistencia a la desaparición", en Caroline Perrée e Ileana Diéguez (coords.), Cuerpos memorables, Centro de Estudios Mexicanos y Centroamericanos, México, pp. $147-164$

CABAllero, Rodrigo

Y Heriberto PAREdES

2019 "La travesía de la Quinta Caravana de Búsqueda por Michoacán”, en Pie de Página, 18 de mayo <https://piedepagina.mx/la-travesiade-la-quinta-caravana-de-busqueda-pormichoacan/> [julio de 2020].

DiÉGuez, Ileana

y Caroline Perrée

2018 "Prefacio. Los cuerpos y las memorias. Vivir y pensar en contextos de violencia", en Caroline Perrée e Ileana Diéguez (coords.), Cuerpos memorables, Centro de Estudios Mexicanos y Centroamericanos, México, pp. 9-26.

Elhaik, Tarek y George Marcus

2012 "Diseño curatorial en la poética y política de la etnografía actual: Una conversación entre Tarek Elhaik y George E. Marcus”, en Íconos. Revista de Ciencias Sociales, núm. 42, enero, pp. 89-104. 
ENCISO, ANGÉlicA

2020 "Gobernación: 61 mil 637, cifra total de desaparecidos", en La Jornada, 7 de enero < https: / / bit.ly/2vvr9or> [ 11 de junio del 2020].

González-Arango, IsABel Cristina

2019 "Repositorio digital para la documentación de textiles testimoniales del conflicto armado en Colombia", tesis de maestría en Ciencias de la Información, Universidad de Antioquia, Medellín, Colombia <https: / / cutt.ly/ccEWM sk $>$ [24 de julio de 2021].

Grau Rebollo, Jordi

2008 "El audiovisual como cuaderno de campo", en Jordi Grau et al., El medio audiovisual como herramienta de investigación social, СІDOв Edicions (Dinámicas interculturales 12), Barcelona, pp.13-30.

INGOLD, TIM

2017 “iSuficiente con la etnografía!”, en Revista Colombiana de Antropología, vol. 53, núm. 2 , julio-diciembre, pp. 143-159.

Jimeno, Myriam, Angela Castillo

Y DANIEL VARELA

2012 "Experiencias de violencia, etnografía y recomposición social en Colombia”, en Myriam Jimeno, Sandra Liliana Murillo y Marco Julián Martínez (eds.), Etnografías contemporáneas. Trabajo de campo, Universidad $\mathrm{Na}$ cional de Colombia (Semilleros), Bogotá, pp. 19-44.

PARKER, ROZSIKA

2010 The subversive stitch. Embroidery and the making of the feminine, I. B. Tauris \& Company, Nueva York.

Pérez-Bustos, TANiA

2019 ¿Puede el bordado (des)tejer la etnografía?", en Disparidades. Revista de Antropología, vol. 74, núm. 1, e002d, pp. 1-7 <https://dra. revistas.csic.es/index.php/dra/article/ view/598/619>. Dor: https: / / doi.org/ 10.3989 /dra.2019.01.002.04 [5 de junio de 2021].

Pérez Hernández, Alba

Y María Viñolo Berenguel

2010 "Las arpilleras, una alternativa textil femenina de participación y resistencia social" <https:/ / docplayer.es / 39849129-Las-arpilleras-una-alternativa-textil-femenina-de-participacion-y-resistencia-social. html $>$ [6 de noviembre del 2021].

PINK, SARAH

2014 "Applied visual anthropology. Social intervention, visual methodologies and Anthropology theory", en Visual Anthropology Review, vol. 20, núm. 1, pp. 3-16.
Quiceno Toro, Natali

y Adriana Marcela Villamizar Gelves

2020 "Mujeres atrateñas, oficios reparadores y espacios de vida", en Revista Colombiana de Antropología, vol. 56, núm. 2, julio-diciembre, pp. $111-137$. DOI: $10.22380 / 2539472 X .702$

Quiñones Aguilar, Cielo

2000 "El tejido en las tribus indígenas de Colombia: unidad y diversidad", en Geografía humana de Colombia. Variación biológica y cultura en Colombia. Tomo 1, Instituto Colombiano de Cultura Hispánica, Bogotá, pp. 80-85 <https: / / babel.banrepcultural.org/digital/ collection / p 1 7054coll 10/id / $2805 / \mathrm{rec} / 1>$ [mayo 2020].

Ramírez Martínez, María del Rosario

2004 "Textiles y letanías visuales en Mesoamérica”, tesis de maestría en Estudios Mesoamericanos, Universidad Nacional Autónoma de México.

Ramírez Morales, María del Rosario

2021 "La experiencia, el cuerpo y el campo en el análisis de las espiritualidades contemporáneas", en Karla Alejandra Contreras Tinoco (coord.), Metodologías, experiencias y prácticas desde la interdisciplina, Universidad de Guadalajara, Ocotlán, pp. 203-226.

\section{Riaño Alcalá, Pilar}

2006 Antropología del recuerdo y el olvido. Jóvenes, memoria y violencia en Medellín, Instituto Colombiano de Antropología e Historia/Editorial Universidad de Antioquia, Medellín.

Rivera García, Mariana X.

2017 "Tejer y resistir. Etnografías audiovisuales y narrativas textiles entre tejedoras amuzgas en el Estado de Guerrero y tejedoras por la memoria en Colombia", tesis de doctorado en Ciencias Antropológicas, Universidad Autónoma Metropolitana-Iztapalapa, México.

Robledo-Silvestre, Carolina

Y MAY-EK QUerales-Mendoza

2020 "Desaparición de personas en el mundo globalizado: desafíos desde América Latina", en Íconos. Revista de Ciencias Sociales, vol. XXIV, núm. 67, pp. 7-15.

Russell, Catherine

1999 Experimental Ethnography, Duke University Press, Londres.

Segarra, Diana

2001 "Coser y cantar: A propósito del tejido y la palabra en la cultura clásica”, en Manuela Marín (ed.), Tejer y vestir: de la Antigüedad al islam, Consejo Superior de Investigaciones Científicas, Madrid, pp. 199-217. 